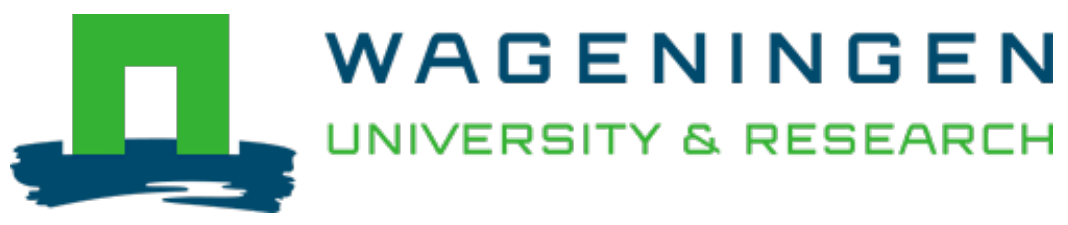

\title{
Impact of sorghum processing on phytate, phenolic compounds and in vitro solubility of iron and zinc in thick porridges
}

\author{
Journal of the Science of Food and Agriculture \\ Kayodé, A.P.P.; Linnemann, A.R.; Nout, M.J.R.; Boekel, M.A.J.S. \\ https://doi.org/10.1002/jsfa.2782
}

This publication is made publicly available in the institutional repository of Wageningen University and Research, under the terms of article $25 \mathrm{fa}$ of the Dutch Copyright Act, also known as the Amendment Taverne. This has been done with explicit consent by the author.

Article 25 fa states that the author of a short scientific work funded either wholly or partially by Dutch public funds is entitled to make that work publicly available for no consideration following a reasonable period of time after the work was first published, provided that clear reference is made to the source of the first publication of the work.

This publication is distributed under The Association of Universities in the Netherlands (VSNU) 'Article $25 \mathrm{fa}$ implementation' project. In this project research outputs of researchers employed by Dutch Universities that comply with the legal requirements of Article $25 \mathrm{fa}$ of the Dutch Copyright Act are distributed online and free of cost or other barriers in institutional repositories. Research outputs are distributed six months after their first online publication in the original published version and with proper attribution to the source of the original publication.

You are permitted to download and use the publication for personal purposes. All rights remain with the author(s) and / or copyright owner(s) of this work. Any use of the publication or parts of it other than authorised under article $25 \mathrm{fa}$ of the Dutch Copyright act is prohibited. Wageningen University \& Research and the author(s) of this publication shall not be held responsible or liable for any damages resulting from your (re)use of this publication.

For questions regarding the public availability of this publication please contact openscience.library@wur.nl 


\title{
Impact of sorghum processing on phytate, phenolic compounds and in vitro solubility of iron and zinc in thick porridges
}

\author{
AP Polycarpe Kayodé, ${ }^{1}$ Anita R Linnemann, ${ }^{2}$ Martinus JR Nout, ${ }^{2 *}$ and \\ Martinus AJS Van Boekel ${ }^{2}$ \\ ${ }^{1}$ Faculté des Sciences Agronomiques, Université d'Abomey-Calavi, 01 BP 526 Cotonou, Bénin \\ ${ }^{2}$ Department of Agrotechnology and Food Sciences, Wageningen University, P.O. Box 8129, 6700 EV Wageningen, the Netherlands
}

\begin{abstract}
This study focussed on the impact of process variables on levels of phytate and phenolic compounds, and in vitro solubility of iron ( $\mathrm{Fe})$ and zinc $(\mathrm{Zn})$ in sorghum porridges, a major staple in semi-arid tropics. The aim was to identify practices that enhance the mineral availability in this type of staple food. We studied the example of the West African porridge 'dibou' for which the processing methods involve grain cleaning, milling, sieving and cooking. Regional variations occur in the process, particularly in the cleaning which may be done wet or dry; sieving may be omitted in certain locations. Cleaning reduced the phytate content of the grain by 24-39\%, while milling, sieving and cooking had no significant effect on phytate. Phenolic compounds measured as levels of reactive hydroxyl groups, remained constant after cleaning, milling and sieving, but significantly decreased by 38-65\% after cooking. The Fe solubility tended to increase after cleaning but was drastically reduced due to cooking, and so was the soluble $\mathrm{Zn}$. Levels of total phenolic compounds highly correlated with the Fe and Zn solubility $\left(r^{2}=0.73\right.$ and 0.82 , respectively). Phenolic reaction products formed during the cooking process are presumably related with the extensive browning phenomenon observed in the dibou porridge, and with the reduction observed in $\mathrm{Fe}$ and $\mathrm{Zn}$ solubility.
\end{abstract}

(C) 2007 Society of Chemical Industry

Keywords: sorghum; porridge; milling; sieving; wet cleaning; cooking

\section{INTRODUCTION}

Iron $(\mathrm{Fe})$ and zinc $(\mathrm{Zn})$ are essential trace elements for human nutrition. They support important functions in the organism; their deficiencies in the diet lead to much suffering, particularly in developing countries where cereals and vegetables are the main sources of macro- and micronutrients for the population. ${ }^{1,2}$ The mineral content and bioavailability in cereals such as sorghum are low due to the presence of anti-nutritional factors such as condensed phenolic compounds and phytate. These form insoluble complexes with essential minerals such as calcium, iron and zinc at physiological $\mathrm{pH}$ levels rendering them unavailable for the organism. ${ }^{2,3}$

Sorghum [Sorghum bicolor (L.) Moench] is an important staple food in semi-arid regions worldwide. ${ }^{4,5}$ The grain is processed into various foods including thin or thick porridges and beverages. Porridges reportedly are most commonly prepared from sorghum. ${ }^{4}$ Dibou, a thick sorghum porridge from Benin is also popular in other countries in the West Africa region. It is known as tô in Burkina-Faso and $o k a-b a b a$ in Nigeria. It is consumed during lunch or dinner as a main dish, with okra (Abelmoschus esculentus), or vegetable soup with meat or fish, depending on the household budget. ${ }^{6}$ In spite of their high frequency of consumption among the sorghum foods, little is known about the micronutrient availability from sorghum porridges.

Basically, the preparation of dibou involves cleaning the sorghum grain, grinding and cooking with variations according to regional traditions. Cleaning may be done simply by dry sorting and winnowing, or wet by washing in water. Likewise, sieving is an optional operation, which may be systematically omitted from, or included in the process. ${ }^{6}$ Also, the cooking time may vary depending on the operators. The impact of these process operations on the levels of micronutrients and their availability in porridge is not yet known, nor understood.

In cereal processing, wet cleaning, grinding and sieving serve to remove debris, germs and bran from the grain. In roller milling of e.g. wheat, wet cleaning induces water uptake of the pericarp, which enhances its flexibility and resistance to friction during milling, permitting its separation from the endosperm in the form of large flakes. ${ }^{7-9}$ Subsequent sieving therefore efficiently removes bran. Anti-nutritional factors, such

* Correspondence to: Martinus JR Nout, Department of Agrotechnology and Food Sciences, Wageningen University, P.O. Box 8129, 6700 EV Wageningen, the Netherlands

E-mail: rob.nout@wur.n

Contract/grant sponsor: Wagenigen University through the North-South Interdisciplinary Research and Education Fund (INREF)

Contract/grant sponsor: International Foundation for Science, Stockholm, Sweden, to A.Kayodé; contract/grant number: IFS E/3736-1

(Received 18 October 2005; revised version received 28 February 2006; accepted 6 July 2006)

Published online 6 February 2007; DOI: 10.1002/jsfa.2782 
as tannins and phytates, are mainly concentrated in the bran and the aleuronic layer of the grain. ${ }^{2,10}$ Against this background and assuming some similarity of roller milling and disc attrition milling such as practised in village-style sorghum processing, it is hypothesised that dibou from sorghum that is washed or/and sieved during processing, contains lower levels of anti-nutritional factors and has higher solubility of $\mathrm{Fe}$ and $\mathrm{Zn}$. No studies were published on the impact of household processing methods on anti-nutritional factors, or $\mathrm{Fe}$ and $\mathrm{Zn}$ solubility in sorghum porridge. Contradictory information exists on the impact of cooking on phytate content of food crops. Fretzdroff and Weiper ${ }^{11}$ reported that cooking at $100^{\circ} \mathrm{C}$ did not affect phytate content of rye flour. Similarly, no reduction in phytate was observed when yam flour was cooked. ${ }^{12}$ But instead, a decrease in phytate content of sorghum and pigeon pea (Cajanus cajan) was observed when the milled grain was cooked. ${ }^{13,14}$

The present study investigated the current household sorghum processing methods to prepare dibou in two communities in the Benin sahelian zone. We focus on the impact of process operations on phytate, phenolic compounds and $\mathrm{Fe}$ and $\mathrm{Zn}$ content, aiming to identify the household practices that enhance the level of $\mathrm{Fe}$ and $\mathrm{Zn}$ solubility in the porridge.

\section{MATERIALS AND METHODS Household survey}

Fifty-two households, previously identified as dibou consumers, were surveyed in two regions (Parakou and Natitingou) of northern Benin. These regions had been selected on the basis of their socio-cultural diversity. Households were chosen randomly and differed from each other in terms of their socio-cultural background. The respondents were the housewives who take care of food preparation for the family. The questionnaire included the following aspects: the sorghum varieties used and quantity processed, the unit operations involved in making dibou, and the quantification of equipments, time and fuel. Occasionally, housewives were closely observed while carrying out the preparation. The protocol used for the survey was approved by the Faculty of Agronomical Sciences of the University of AbomeyCalavi; informed consent was obtained from all participating households.

\section{Processing and sampling}

One batch of red sorghum [Sorghum bicolor (L.) Moench] was purchased at a local market in Parakou and processed into dibou following three representative process scenarios resulting from the survey (Fig. 1). Five kilograms of grain were processed into dibou by duplicate households for each process scenario. Samples - sorghum grain, semi-processed grain and porridges - were withdrawn at each process step, dried in an oven, ground into flour using a Retsch mill

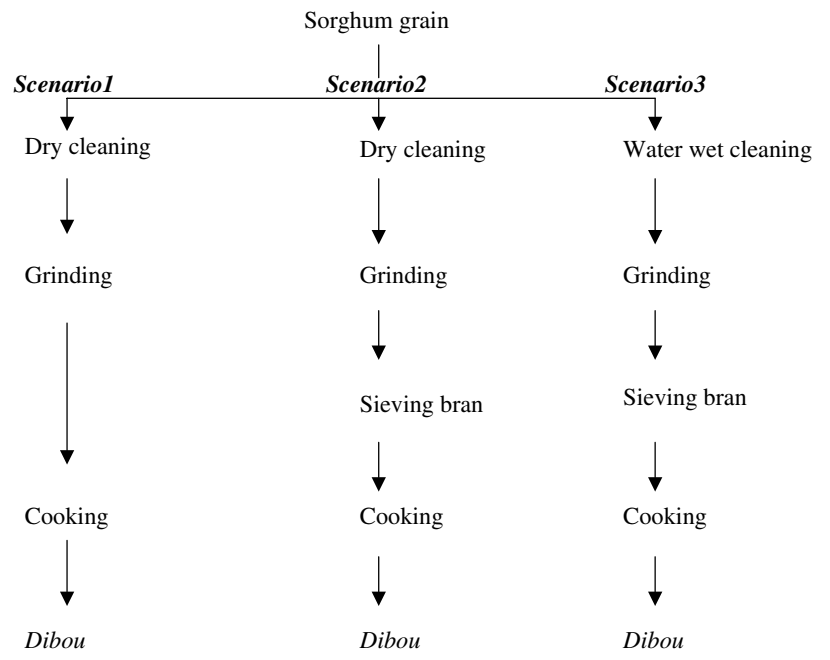

Figure 1. Process diagrams showing the three scenarios of dibou production.

(Retsch bv, type ZM 1; Haan, Germany) fitted with a $0.5 \mathrm{~mm}$ screen and stored at $-20^{\circ} \mathrm{C}$ until analysis.

\section{In vitro digestion of samples for analysis of soluble Fe and Zn}

The in vitro digestion method ${ }^{15}$ was used, with minor modifications. Duplicate dry samples of flour (5 g) were suspended in $30 \mathrm{~mL}$ distilled water and digested under simulated gastro-intestinal conditions, using $\alpha$-amylase solution (Sigma A-1031; Sigma-Aldrich, Zwijndrecht, The Netherlands), stomach medium consisting of lipase (Rhizopus F-AP15; Amano Pharmaceuticals, Chipping Norton, UK) and pepsin (Sigma P-6887), and pancreatic solution consisting of pancreatin (Sigma P-1750) and bile (Sigma B3883). After digestion, the suspension was centrifuged at $3600 \times g$ for $15 \mathrm{~min}$ at $4{ }^{\circ} \mathrm{C}$. The supernatant was decanted and the pellet was washed twice in $20 \mathrm{~mL}$ of distilled water and centrifuged. The supernatants were pooled and filtered through a $0.45 \mu \mathrm{m}$ pore filter. A blank was included consisting of $30 \mathrm{~mL}$ distilled water digested and filtered as described above. Both filtered supernatants from sample and blank were analysed for $\mathrm{Fe}$ and $\mathrm{Zn}$. Samples were corrected for added reagents/water by subtracting $\mathrm{Fe}$ and $\mathrm{Zn}$ content of blank from that of supernatants from samples. The amounts of $\mathrm{Fe}$ and $\mathrm{Zn}$ (expressed as $\mathrm{mg} \mathrm{kg}^{-1}$ of digested sample) in supernatant were regarded as soluble minerals. Percentage of soluble mineral was calculated as

$$
\frac{S_{\mathrm{Fe} / \mathrm{Zn}}-B_{\mathrm{Fe} / \mathrm{Zn}}}{U_{\mathrm{Fe} / \mathrm{Zn}}} \times 100
$$

where $S_{\mathrm{Fe} / \mathrm{Zn}}$ is the concentration of $\mathrm{Fe}$ or $\mathrm{Zn}$ in the supernatant; $B_{\mathrm{Fe} / \mathrm{Zn}}$ is the concentration of $\mathrm{Fe}$ or $\mathrm{Zn}$ in the blank; and $U_{\mathrm{Fe} / \mathrm{Zn}}$ is the concentration of $\mathrm{Fe}$ or $\mathrm{Zn}$ in the undigested sample. 


\section{Physico-chemical analysis}

$F e$ and $Z n$ determination

Approximately $0.4 \mathrm{~g}$ of sorghum flour was digested using hydrofluoric acid (40\%) and concentrated nitric acid $(65 \% \mathrm{w} / \mathrm{w})$. Next, the concentrations of $\mathrm{Fe}$ and $\mathrm{Zn}$ were analysed by using an inductively coupled plasma-optical emission spectrometer (ICP-OES, Elan 6000, Perkin Elmer, Wellesley, MA, USA). ${ }^{16}$ Samples from in vitro digestion were collected in tubes $(10 \mathrm{~mL})$ and $0.15 \mathrm{~mL}$ of concentrated nitric acid $\left(\mathrm{HNO}_{3} 65 \%\right)$ was added to preserve them. These samples were analysed by using ICP-MS (Elan 6000). Measurements were performed in duplicate.

\section{Phytate determination}

Approximately $10 \mathrm{mg}$ of grain flour was extracted with $1 \mathrm{~mL}$ of $0.5 \mathrm{~mol} \mathrm{~L}^{-1} \mathrm{HCl}$ containing $50 \mathrm{mg}$ $\mathrm{L}^{-1}$ cis-aconitate (internal standard). ${ }^{17}$ The mixture was boiled in a water bath at $100^{\circ} \mathrm{C}$ for $15 \mathrm{~min}$ and then centrifuged at $14000 \times g$ for $10 \mathrm{~min}$. The supernatant was diluted $5 \times$ in millipore water and analysed using HPLC (Dionex DX300, ICS2500 system, detector range of $10 \mu \mathrm{S}$; Sunnyvale, CA) using the column AS11 (ATC column + guard column; Dionex). Detection was with suppressed conductivity and the suppression was done with water at a flow rate of $5 \mathrm{~mL} \mathrm{~min}^{-1}$. The eluent and the elution times used are as follows: $0-5 \mathrm{~min}, 5 \mathrm{mmol} \mathrm{L}^{-1} \mathrm{NaOH}$; 5-15 min, 5-100 mmol L $\mathrm{L}^{-1} \mathrm{NaOH} ; 15-20 \mathrm{~min}$, $500 \mathrm{mmol} \mathrm{L}^{-1} \mathrm{NaOH}$ and $20-35 \mathrm{~min}, 5 \mathrm{mmol} \mathrm{L}^{-1}$ $\mathrm{NaOH}$. A standard solution was prepared in millipore water, which contains $5.0 \mathrm{mg} \mathrm{L}^{-1} \mathrm{NaNO}_{3}$ (Merck p.a., Darmstadt, Germany), $5.0 \mathrm{mg} \mathrm{L}^{-1} \mathrm{Na}_{2} \mathrm{SO}_{4}$, (Merck p.a.), $5.0 \mathrm{mg} \mathrm{L}^{-1}$ oxalic acid $\cdot 2 \mathrm{H}_{2} \mathrm{O}$ (Merck p.a.), $10.0 \mathrm{mg} \mathrm{L} \mathrm{Na}_{2} \mathrm{HPO}_{4} \cdot 2 \mathrm{H}_{2} \mathrm{O}$ (Merck 6346 p.a.), $10 \mathrm{mg} \mathrm{L}^{-1}$ citric acid, $\mathrm{H}_{2} \mathrm{O}$ (Merck K23524044 719 p.a.), $5.0 \mathrm{mg} \mathrm{L}^{-1}$ cis-aconitate (Aldrich $27194-2$, Sigma-Aldrich, Zwijndrecht, The Netherlands) and $10 \mathrm{mg} \mathrm{L}^{-1} \mathrm{IP}_{6} \cdot \mathrm{Na}_{12}$ (Sigma P3168 lot 102K0053). Measurements were performed in triplicate.

\section{Total phenolics determination}

Total phenolic compounds (PCs) were extracted from $50 \mathrm{mg}$ of flour in $1.5 \mathrm{~mL}$ of $\mathrm{HCl} / \mathrm{methanol}(1 \% \mathrm{v} / \mathrm{v})$ for $1 \mathrm{~h}$ under continuous stirring at room temperature. The mixture was centrifuged at $5000 \times g$ for $10 \mathrm{~min}$ and supernatant was removed. Next the pellet was re-extracted as described above and supernatants were pooled. ${ }^{18}$ The PCs were measured following the method of Singleton and Rossi ${ }^{19}$ modified as follows: $300 \mu \mathrm{L}$ of extract were added with $4.2 \mathrm{~mL}$ of distilled water, $0.75 \mathrm{~mL}$ of Folin-Ciocalteu reagent (Merck, Germany) and $0.75 \mathrm{~mL}$ of sodium carbonate solution $(20 \% \mathrm{w} / \mathrm{v})$. After incubation for $30 \mathrm{~min}$ the optical density was measured at $760 \mathrm{~nm}$ using a spectrophotometer (Shimadzu UV 240, Kyoto, Japan). Blanks were always freshly prepared, in which Folin-Ciocalteu reagent was replaced by water to correct for interfering compounds. Gallic acid (Aldrich Chemical Company, New Jersey, USA) was used as standard and the results were expressed as gallic acid equivalent per gram of sample.

\section{Crude protein, ash and colour measurement}

Crude protein $(\mathrm{N} \times 6.25)$ and ash were determined according to the AOAC method. ${ }^{20}$ The colour of the grain samples was measured with a Minolta CR-210 portable chromameter (Illuminant D65 CIE 1976, Minolta, Tokyo, Japan) standardised with a standard white tile $(Y=94.8, x=0.315$ and $y=0.3324)$. The $L, a^{*}, b^{*}$ values were recorded ( $L=$ whiteness index, $a^{*}=$ redness index, $b^{*}=$ yellowness index) and the browning index was calculated as: $\mathrm{BI}=100-L^{21}$ Because adding water to flour may lead to colour changes as observed in our own experiments (data not shown), we took this into account in the interpretation of data on cooked flour.

\section{Statistical analysis}

Survey data were analysed using Winstat 2.0 software (CIRAD, Montpellier, France). For the analytical data, mean values and standard deviation are reported. The data were analysed using the statistical program SPSS 11.0 (SPSS, Chicago, IL, USA) and the oneway ANOVA model was used applying the LSD test to evaluate significant difference among means.

\section{RESULTS AND DISCUSSION Variation in household dibou processing}

The unit operations involved in dibou preparation and the percentage of households using them are presented in Table 1. In general, dibou preparation involves cleaning, grinding, sieving and cooking. Cleaning may consist exclusively of a simple sorting and winnowing of grains ( $70 \%$ of households), or washing in water $(30 \%)$. The proportion of households using dry or wet cleaning methods depends on the region. In Natitingou, most of the processors sort the grain, while in Parakou, half of the households use sorting while the other half wash to clean the grains. Sieving is not used by $40 \%$; most households that sieve the flour are located in Parakou. These process variations lead to three scenarios of dibou preparation as shown in Fig. 1. The housewives interviewed explained that the main reasons for washing the grain or sieving the flour, are to improve the palatability and to enhance the

Table 1. Frequency of use of unit process operations involved in dibou preparation by 52 households from two regional communities in Northern Benin (in \% of $n$ respondents)

\begin{tabular}{lccr}
\hline $\begin{array}{l}\text { Unit } \\
\text { operation }\end{array}$ & $\begin{array}{c}\text { Parakou } \\
(n=30)\end{array}$ & $\begin{array}{c}\text { Natitingou } \\
(n=22)\end{array}$ & $\begin{array}{c}\text { Total } \\
(\mathrm{n}=52)\end{array}$ \\
\hline Sorting & 52 & 95 & 70 \\
Washing & 48 & 5 & 29 \\
Drying & 48 & 5 & 29 \\
Grinding & 100 & 100 & 100 \\
Sieving & 90 & 18 & 60 \\
Cooking & 100 & 100 & 100 \\
\hline
\end{tabular}


textural properties (particularly the elasticity) of the final product. Most processors in Natitingou perceived washing and sieving as time-consuming tasks, which explains the low proportion of households using these operations there. Indeed, washing necessitates a drying step, which takes $1-2 \mathrm{~h}$ depending on solar intensity. Processors in Natitingou sometimes add cassava chips to the grain to obtain the desired texture (elasticity) in the paste; we did not take this addition into account in the comparison of processing scenarios. In the following sections the nutritional impacts of the different scenarios are discussed.

\section{Impact on total Fe and Zn content}

The variations in $\mathrm{Fe}$ and $\mathrm{Zn}$ content of sorghum grain during dibou preparation following the three process scenarios are presented in Table 2 . The $\mathrm{Zn}$ content of the grain remains constant throughout the process with a slight increase after cooking, possibly due to contamination from the metallic cooking pot. The Fe and ash (in scenarios 2 and 3 ) content also increased after cooking. The washing process (scenario 3) significantly reduces the grain-Fe by $67 \%$. The mineral balance (Table 3) also reveals a significant loss in $\mathrm{Fe}$ after the washing process in scenario 3. Indeed, the $\mathrm{Fe}$ content of the grain $\left(256 \mathrm{mg} \mathrm{kg}^{-1}\right)$ found in this study is high when compared to earlier values reported for sorghum seed. Kayodé et al. ${ }^{22}$ reported a mean value of $57.5 \mathrm{mg} \mathrm{kg}^{-1}$ with a range of $32-99$ in 45 sorghum genotypes from northern Benin. Jambunathan $^{23}$ reported an average $\mathrm{Fe}$ content of $59 \mathrm{mg} \mathrm{kg}^{-1}$ with a range of $26-96 \mathrm{mg} \mathrm{kg}^{-1}$ in samples of about 100 varieties of sorghum. The origin of our grain, which was bought at a local market, may be responsible for this discrepancy. The grain may have been contaminated during post-harvest treatments, notably during the threshing, which consist of beating the ears on the ferruginous soil. The fact that the Fe content of the grain was drastically reduced after washing (scenario 3) supports this hypothesis. Unexpectedly, sieving did not affect the mineral content of the flour. This can be explained by the fact that grinding reduced the grain into fine powder and subsequent sieving did not result in the selective separation of e.g. testa. The analysis of mass balances (Table 3) showed a slight loss of coarse material due to sieving.

Table 3. Balances of mass ${ }^{1}$, Fe and $\mathrm{Zn}$ during dibou preparation

\begin{tabular}{lccc}
\hline & Mass $(\mathrm{kg} \mathrm{dm})^{2}$ & Fe $(\mathrm{g} \mathrm{dm})$ & Zn $(\mathrm{g} \mathrm{dm})$ \\
\hline Scenario 1 & (dry cleaning - grinding - cooking) & \\
Raw & $100 \pm 0.0^{\mathrm{a}}$ & $25.6 \pm 2.5^{\mathrm{a}}$ & $2.5 \pm 0.1^{\mathrm{a}}$ \\
Cleaned & $94.8 \pm 0.3^{\mathrm{b}}$ & $16.8 \pm 2.9^{\mathrm{a}}$ & $2.4 \pm 0.6^{\mathrm{ab}}$ \\
Ground & $87.5 \pm 2.0^{\mathrm{c}}$ & $15.5 \pm 2.4^{\mathrm{b}}$ & $2.3 \pm 0.9^{\mathrm{b}}$ \\
Cooked & $84.5 \pm 0.2^{\mathrm{d}}$ & $18.0 \pm 4.4^{\mathrm{a}}$ & $2.3 \pm 0.9^{\mathrm{b}}$ \\
Scenario 2 & (dry cleaning - grinding - sieving - & cooking) \\
Raw & $100 \pm 0.0^{\mathrm{a}}$ & $25.6 \pm 2.5^{\mathrm{a}}$ & $2.5 \pm 0.1^{\mathrm{a}}$ \\
Cleaned & $96.2 \pm 1.7^{\mathrm{b}}$ & $29.2 \pm 6.7^{\mathrm{a}}$ & $2.6 \pm 0.1^{\mathrm{a}}$ \\
Ground & $92.5 \pm 0.5^{\mathrm{bc}}$ & $28.1 \pm 7.0^{\mathrm{a}}$ & $2.5 \pm 0.3^{\mathrm{a}}$ \\
Sieved & $90.3 \pm 1.3^{\mathrm{c}}$ & $25.1 \pm 3.6^{\mathrm{a}}$ & $2.3 \pm 0.3^{\mathrm{a}}$ \\
Cooked & $82.5 \pm 2.5 \mathrm{~d}$ & $26.0 \pm 4.4^{\mathrm{a}}$ & $2.5 \pm 0.4^{\mathrm{a}}$ \\
Scenario 3 (wet cleaning - grinding - sieving & cooking) \\
Raw & $100 \pm 0.0^{\mathrm{a}}$ & $25.6 \pm 2.5^{\mathrm{a}}$ & $2.5 \pm 0.1^{\mathrm{a}}$ \\
Cleaned & $95.5 \pm 2.7^{\mathrm{ab}}$ & $6.8 \pm 0.4^{\mathrm{b}}$ & $2.5 \pm 0.2^{\mathrm{a}}$ \\
Ground & $89.4 \pm 6.1^{\mathrm{bc}}$ & $6.3 \pm 0.6^{\mathrm{b}}$ & $2.3 \pm 0.3^{\mathrm{a}}$ \\
Sieved & $85.3 \pm 4.6^{\mathrm{c}}$ & $5.9 \pm 0.3^{\mathrm{b}}$ & $2.2 \pm 0.2^{\mathrm{a}}$ \\
Cooked & $79.9 \pm 1.3^{\mathrm{c}}$ & $7.9 \pm 0.1^{\mathrm{b}}$ & $2.2 \pm 0.2^{\mathrm{a}}$ \\
\hline
\end{tabular}

${ }^{1}$ The quantity of product obtained at each process step was carefully weighed during dibou processing, using a scale. The generated values were combined with data on dry matter, $\mathrm{Fe}$ and $\mathrm{Zn}$ concentrations of the different products, to calculate the data presented in this table.

${ }^{2}$ Means \pm standard deviation, means with the same letter are not significantly different according to the LSD at the 0.05 level

Table 2. Changes in iron, zinc, ash, crude protein and phenolics content of sorghum grain during dibou preparation

\begin{tabular}{|c|c|c|c|c|c|c|c|}
\hline & $\begin{array}{c}\text { Total Fe } \\
\left(\mathrm{mg} \mathrm{kg}^{-1} \mathrm{dm}\right)\end{array}$ & $\begin{array}{c}\mathrm{IVS}^{2} \mathrm{Fe} \\
\left(\mathrm{mg} \mathrm{kg}^{-1} \mathrm{dm}\right)\end{array}$ & $\begin{array}{c}\text { Total Zn } \\
\left(\mathrm{mg} \mathrm{kg}^{-1} \mathrm{dm}\right)\end{array}$ & $\begin{array}{c}\text { IVS Zn } \\
\left(\mathrm{mg} \mathrm{kg}^{-1} \mathrm{dm}\right)\end{array}$ & $\begin{array}{c}\text { Ash (g } \\
\left.100 \mathrm{~g}^{-1} \mathrm{dm}\right)\end{array}$ & $\begin{array}{l}\text { Crude protein } \\
\left(\mathrm{g} 100 \mathrm{~g}^{-1} \mathrm{dm}\right)\end{array}$ & $\begin{array}{l}\text { Total phenolics } \\
\left.\text { (g } 100 \mathrm{~g}^{-1} \mathrm{dm}\right)\end{array}$ \\
\hline \multicolumn{8}{|c|}{ Scenario 1 (dry cleaning - grinding - cooking) } \\
\hline Raw & $255.8 \pm 25.2^{a}$ & $15.1 \pm 0.6^{a}$ & $25.4 \pm 0.5^{a}$ & $8.4 \pm 0.6^{a}$ & $1.8 \pm 0.0^{a}$ & $10.5 \pm 0.1^{a}$ & $0.22 \pm 0.00^{a}$ \\
\hline Cleaned & $177.8 \pm 38.3^{a}$ & $34.9 \pm 7.5^{\mathrm{b}}$ & $25.7 \pm 0.7^{a}$ & $7.9 \pm 0.3^{a}$ & $1.8 \pm 0.1^{\mathrm{a}}$ & $10.2 \pm 0.2^{a}$ & $0.26 \pm 0.01^{a}$ \\
\hline Ground & $178.5 \pm 37.5^{\mathrm{a}}$ & $34.0 \pm 0.7^{b}$ & $24.5 \pm 0.3^{a}$ & $7.3 \pm 0.8^{\mathrm{a}}$ & $1.8 \pm 0.0^{\mathrm{a}}$ & $10.1 \pm 0.1^{a}$ & $0.26 \pm 0.01^{\mathrm{a}}$ \\
\hline Cooked & $212.7 \pm 43.6^{a}$ & $13.2 \pm 1.7^{\mathrm{a}}$ & $27.0 \pm 1.5^{\mathrm{a}}$ & $3.4 \pm 3.7^{b}$ & $1.8 \pm 0.3^{a}$ & $10.1 \pm 0.2^{a}$ & $0.16 \pm 0.02^{b}$ \\
\hline \multicolumn{8}{|c|}{ Scenario 2 (dry cleaning - grinding - sieving - cooking) } \\
\hline Raw & $255.8 \pm 25.2^{a}$ & $15.1 \pm 0.6^{\mathrm{a}}$ & $25.4 \pm 0.5^{a}$ & $8.4 \pm 0.6^{\mathrm{a}}$ & $1.8 \pm 0.0^{\mathrm{a}}$ & $10.5 \pm 0.1^{\mathrm{a}}$ & $0.22 \pm 0.00^{\mathrm{a}}$ \\
\hline Cleaned & $304.1 \pm 64.5^{\mathrm{a}}$ & $25.3 \pm 2.0^{b}$ & $27.2 \pm 1.4^{a}$ & $9.2 \pm 0.3^{a}$ & $1.9 \pm 0.3^{b}$ & $9.7 \pm 0.2^{b}$ & $0.23 \pm 0.02^{a}$ \\
\hline Ground & $310.4 \pm 57.4^{a}$ & $25.8 \pm 1.2^{b}$ & $26.8 \pm 1.3^{a}$ & $9.4 \pm 0.7^{a}$ & $1.8 \pm 0.2^{b}$ & $9.7 \pm 0.1^{b}$ & $0.23 \pm 0.00^{a}$ \\
\hline Sieved & $277.7 \pm 31.0^{a}$ & $26.5 \pm 0.3^{b}$ & $25.7 \pm 0.8^{a}$ & $8.7 \pm 0.1^{a}$ & $1.9 \pm 0.1^{b}$ & $9.7 \pm 0.3^{b}$ & $0.23 \pm 0.02^{a}$ \\
\hline Cooked & $314.1 \pm 36.7^{a}$ & $8.6 \pm 1.8^{c}$ & $30.5 \pm 6.3^{a}$ & $2.1 \pm 1.1^{b}$ & $2.0 \pm 0.2^{b}$ & $10.7 \pm 0.4^{a}$ & $0.08 \pm 0.02^{b}$ \\
\hline \multicolumn{8}{|c|}{ Scenario 3 (wet cleaning - grinding - sieving - cooking) } \\
\hline Raw & $255.8 \pm 25.2^{a}$ & $15.1 \pm 0.6^{a}$ & $25.4 \pm 0.5^{\mathrm{a}}$ & $8.4 \pm 0.6^{a}$ & $1.8 \pm 0.0^{\mathrm{a}}$ & $10.5 \pm 0.1^{\mathrm{a}}$ & $0.22 \pm 0.00^{a}$ \\
\hline Cleaned & $70.7 \pm 3.1^{b}$ & $14.8 \pm 0.9^{a}$ & $26.2 \pm 1.6^{\mathrm{a}}$ & $6.0 \pm 1.3^{b}$ & $1.7 \pm 0.1^{b}$ & $9.8 \pm 0.6^{\mathrm{a}}$ & $0.24 \pm 0.01^{\mathrm{a}}$ \\
\hline Ground & $73.1 \pm 7.4^{b}$ & $14.1 \pm 0.5^{\mathrm{a}}$ & $27.2 \pm 0.9^{a}$ & $5.4 \pm 1.1^{\mathrm{b}}$ & $1.7 \pm 0.1^{b}$ & $9.7 \pm 02^{\mathrm{a}}$ & $0.24 \pm 0.01^{a}$ \\
\hline Sieved & $69.2 \pm 0.4^{b}$ & $14.3 \pm 0.7^{\mathrm{a}}$ & $26.0 \pm 0.9^{a}$ & $5.8 \pm 0.7^{b}$ & $1.7 \pm 0.4^{b}$ & $9.8 \pm 0.3^{a}$ & $0.23 \pm 0.02^{a}$ \\
\hline Cooked & $99.4 \pm 0.6^{c}$ & $6.3 \pm 0.6^{b}$ & $28.1 \pm 0.1^{c}$ & $1.9 \pm 0.0^{c}$ & $2.1 \pm 0.1^{c}$ & $9.9 \pm 0.8^{a}$ & $0.15 \pm 0.04^{b}$ \\
\hline
\end{tabular}

\footnotetext{
${ }^{1}$ Means \pm standard deviation, means with the same letter are not significantly different according to the LSD at the 0.05 level; ${ }^{2}$ IVS: in vitro soluble
} 
Table 4. Changes in phytate (IP6) and in vitro soluble ratio iron and zinc in sorghum grain during dibou preparation

\begin{tabular}{lcrc}
\hline & IP6 $\left(\mathrm{g} 100 \mathrm{~g}^{-1} \mathrm{dm}\right)^{1}$ & IVS Ratio Fe & \\
\hline Scenario 1 & (dry cleaning - grinding - cooking) & \\
Raw & $0.80 \pm 0.13^{\mathrm{a}}$ & $5.9 \pm 0.3^{\mathrm{a}}$ & $33.3 \pm 2.4^{\mathrm{a}}$ \\
Cleaned & $0.61 \pm 0.12^{\mathrm{b}}$ & $19.9 \pm 3.7^{\mathrm{b}}$ & $30.6 \pm 1.9^{\mathrm{a}}$ \\
Ground & $0.61 \pm 0.12^{\mathrm{b}}$ & $20.0 \pm 0.5^{\mathrm{b}}$ & $29.9 \pm 1.3^{\mathrm{a}}$ \\
Cooked & $0.70 \pm 0.06^{\mathrm{b}}$ & $6.3 \pm 0.6^{\mathrm{a}}$ & $5.6 \pm 3.0^{\mathrm{b}}$ \\
Scenario 2 & (dry cleaning - grinding - sieving - cooking) \\
Raw & $0.80 \pm 0.13^{\mathrm{a}}$ & $5.9 \pm 0.3^{\mathrm{a}}$ & $33.3 \pm 2.4^{\mathrm{a}}$ \\
Cleaned & $0.60 \pm 0.01^{\mathrm{b}}$ & $8.7 \pm 2.6^{\mathrm{b}}$ & $33.9 \pm 1.3^{\mathrm{a}}$ \\
Ground & $0.60 \pm 0.01^{\mathrm{b}}$ & $8.9 \pm 2.5^{\mathrm{b}}$ & $33.6 \pm 1.1^{\mathrm{a}}$ \\
Sieved & $0.59 \pm 0.04^{\mathrm{b}}$ & $9.6 \pm 1.2^{\mathrm{b}}$ & $33.7 \pm 1.0^{\mathrm{a}}$ \\
Cooked & $0.62 \pm 0.06^{\mathrm{b}}$ & $2.8 \pm 0.9^{\mathrm{c}}$ & $7.3 \pm 4.5^{\mathrm{b}}$ \\
Scenario 3 (wet cleaning - grinding - sieving & - cooking) \\
Raw & $0.80 \pm 0.13^{\mathrm{a}}$ & $5.9 \pm 0.3^{\mathrm{a}}$ & $33.3 \pm 2.4^{\mathrm{a}}$ \\
Cleaned & $0.49 \pm 0.07^{\mathrm{b}}$ & $20.9 \pm 1.4^{\mathrm{b}}$ & $22.6 \pm 3.9^{\mathrm{b}}$ \\
Ground & $0.49 \pm 0.07^{\mathrm{b}}$ & $20.9 \pm 1.3^{\mathrm{b}}$ & $22.1 \pm 2.9^{\mathrm{b}}$ \\
Sieved & $0.51 \pm 0.09^{\mathrm{b}}$ & $20.6 \pm 1.2^{\mathrm{b}}$ & $22.1 \pm 2.1^{\mathrm{b}}$ \\
Cooked & $0.51 \pm 0.16^{\mathrm{b}}$ & $6.3 \pm 0.6^{\mathrm{c}}$ & $7.0 \pm 0.0^{\mathrm{c}}$ \\
\hline
\end{tabular}

${ }^{1}$ Means \pm standard deviation, means with the same letter are not significantly different according to the LSD at the 0.05 level; ${ }^{2}$ in vitro soluble ratio $\mathrm{Fe}=\left[\left\{\mathrm{IVSFe}\left(\mathrm{mg} \mathrm{kg}^{-1} \mathrm{dm}\right)\right\} /\left\{\right.\right.$ Total Fe $\left.\left.\left(\mathrm{mg} \mathrm{kg}^{-1} \mathrm{dm}\right)\right\}\right] \times$ $100 ;{ }^{3}$ in vitro soluble ratio $\mathrm{Zn}=\left[\left\{\mathrm{IVS} \mathrm{Zn}\left(\mathrm{mg} \mathrm{kg}^{-1} \mathrm{dm}\right)\right\} /\{\right.$ Total $\mathrm{Zn}$ $\left.\left.\left(\mathrm{mg} \mathrm{kg}^{-1} \mathrm{dm}\right)\right\}\right] \times 100$

\section{Impact on phytate and total phenolics}

Table 4 shows a grain-phytate level of $0.8 \%$; this is in agreement with earlier findings. ${ }^{24,25}$ As can be seen in Table 4, cleaning reduces the phytate content of the grain by $24-25 \%$ after dry cleaning (scenarios 1 and 2), and by $39 \%$ after wet cleaning (scenario 3), respectively. The decrease from cleaning is greater than achieved by soaking, where $16-21 \%$ phytate reduction was reported, ${ }^{13}$ but is similar to decreases caused by germination. ${ }^{24}$ Thus, cleaning can significantly contribute to phytate removal from sorghum-based foods. The decreased phytate content may be due to removal of exogenous materials such as grains with attached glumes, spoiled grains, and attrition dust. The wet cleaning appeared to be more efficient in removing these exogenous particles.

Cooking did not affect the phytate content, in contrast to another observation of decreased phytate content of sorghum flour after cooking. ${ }^{13}$ Our results resembled findings for yam and rye flour, in which phytate was reported to be stable under the ordinary wet cooking conditions. ${ }^{11,12}$ The total phenolic compounds measured by their reactive hydroxyl groups, significantly decreased during cooking in all process scenarios (Table 2), the decrease ranging from 38 to $65 \%$. During heating, the phenolic hydroxyl groups may have reacted, or formed insoluble complexes with food components such as protein and minerals, or even polymerised into condensed phenolics leading to a decrease of assayable phenolic hydroxylic groups. ${ }^{26-28}$
Table 5. Pearson correlation matrix between IVS Fe, IVS Zn, Phytate (IP6), reactive phenolic hydroxyl groups and the browning index of sorghum

\begin{tabular}{lccrc}
\hline & IVS Fe & IVS Zn & IP6 & PC \\
\hline $\mathrm{IVS}^{1} \mathrm{Zn}$ & 0.359 & & & \\
$\mathrm{IP6}$ & 0.398 & -0.477 & & \\
$\mathrm{PC}^{2}$ & $0.729^{*}$ & $0.823^{* *}$ & -0.339 & \\
$\mathrm{BI}^{3}$ & $-0.667^{*}$ & $-0.912^{* *}$ & 0.580 & $-0.921^{* *}$ \\
\hline
\end{tabular}

** Correlation is significant at the 0.01 level; * Correlation is significant at the 0.05 level; ${ }^{1}$ IVS: in vitro soluble; ${ }^{2}$ PC:total phenolic compounds;

${ }^{3} \mathrm{BI}$ :browning index $(\mathrm{BI}=100-\mathrm{L}, \mathrm{L}$ is the whiteness index).

\section{Impact on in vitro solubility of Fe and $\mathrm{Zn}$}

The levels of soluble $\mathrm{Fe}$ and $\mathrm{Zn}$ at each process step are presented in Table 2. In the final product (dibou) the level of soluble Fe ranged from 6.2 to $13.3 \mathrm{mg} \mathrm{kg}^{-1}$ with an average of $9.4 \mathrm{mg} \mathrm{kg}^{-1}$ (dry basis). Values for soluble $\mathrm{Zn}$ ranged from 1.9 to $3.4 \mathrm{mg} \mathrm{kg}^{-1}$ with an average of $2.5 \mathrm{mg} \mathrm{kg}^{-1}$. In all scenarios the in vitro soluble $\mathrm{Fe}$ increased significantly after cleaning and remained quite constant after grinding and sieving. This trend seems to follow the changes in phytate content, which decreased after cleaning and remained constant after grinding and sieving (see above). The myo-inositol hexakisphosphate (IP6) is the major inhibitor of $\mathrm{Fe}$ and $\mathrm{Zn}$ absorption from plant foods, and lowering the levels of phytic acid in meals of plant origin could greatly improve the absorption of these minerals. ${ }^{2}$ Contrary to our expectation, no correlation could be established between $\mathrm{Zn}$ solubility and the phytate content of the flours. Possibly, this is related to the fact that $\mathrm{Fe}$ and $\mathrm{Zn}$ are not located in the same place in the seed. $\mathrm{Zn}$ is found in a large number of enzymes and other proteins and is distributed throughout the seed. ${ }^{29} \mathrm{Fe}$ in seeds is stored as phytoferritin or phytate, mainly concentrated in the bran and the aleuronic layer of the grain. ${ }^{2,10}$

During the three process scenarios studied, cooking drastically reduced the in vitro $\mathrm{Fe}$ and $\mathrm{Zn}$ solubility in the porridge. This reduction could not be linked to the inhibitory effect of phytate, which remained constant after cooking. After cooking, a 56-68\% reduction in soluble $\mathrm{Fe}$ occurred and the solubility in $\mathrm{Zn}$ was reduced by $57-76 \%$. Matuscheck et al. ${ }^{28}$ also reported a significant decrease of in vitro soluble $\mathrm{Fe}$ after cooking sorghum flour and related this to the chelating effect of phytate and phenolic compounds. Phenolic compounds, especially condensed phenolics such as tannins, are also reported to chelate divalent minerals, i.e. $\mathrm{Fe}$ and $\mathrm{Zn} .^{2}$ Our results indicate significant positive correlations $(P<0.01)$ between the level of reactive phenolic hydroxyl groups and the $\mathrm{Fe}$ and Zn solubility (Table 5). During heat treatments, e.g. cooking, the phenolic compounds can polymerise into condensed phenolics leading to a decrease of the assayable total phenolics. Hence in this study, we suspected the condensed phenolics to be responsible for the considerable decrease of soluble $\mathrm{Fe}$ and $\mathrm{Zn}$ observed after cooking. The extensive browning 
Table 6. Colour changes of sorghum during dibou preparation

\begin{tabular}{lccc}
\hline & \multicolumn{3}{c}{ Browning index $(\mathrm{Bl}=100-\mathrm{L})$} \\
\hline Scenario 1 & Scenario 2 & Scenario 3 \\
Raw & $23.6 \pm 0.7^{\mathrm{a} 1}$ & $23.6 \pm 0.7^{\mathrm{a}}$ & $23.6 \pm 0.7^{\mathrm{a}}$ \\
Cleaned & $23.6 \pm 0.7^{\mathrm{a}}$ & $23.7 \pm 0.2^{\mathrm{a}}$ & $22.2 \pm 0.1^{\mathrm{a}}$ \\
Ground & $23.6 \pm 0.6^{\mathrm{a}}$ & $23.7 \pm 0.2^{\mathrm{a}}$ & $22.2 \pm 0.1^{\mathrm{a}}$ \\
Sieved & - & $23.7 \pm 0.3^{\mathrm{a}}$ & $22.2 \pm 0.2^{\mathrm{a}}$ \\
Cooked & $49.3 \pm 1.3^{\mathrm{b}}$ & $50.3 \pm 1.2^{\mathrm{b}}$ & $46.6 \pm 0.2^{\mathrm{b}}$ \\
\hline
\end{tabular}

${ }^{1}$ Means \pm standard deviation, means with the same letter are not significantly different according to the LSD at the 0.05 level.

of the flour observed after cooking (Table 6) and the coloration behaviour associated with condensed phenolic compounds ${ }^{2,3}$ would support this hypothesis.

\section{CONCLUSION}

The present study evaluated the impact of process unit operations used to prepare sorghum thick porridge (dibou) at the poorest household level in Benin, on the in vitro solubility of micronutrients. Cleaning, especially wet cleaning, significantly contributes to phytate removal from sorghum grain and results in better Fe solubility. Sieving of milled grain as currently applied, is less effective in achieving reduction of phytate and phenolic contents of the grain flour. Sieving might be more efficient if grains are first conditioned by moistening and then coarsely ground, prior to sieving. Cooking was found to be the main unit operation that restricts the $\mathrm{Fe}$ and $\mathrm{Zn}$ availability in porridge. Further research is recommended to identify the inhibitors of mineral solubility generated during cooking, and to develop approaches that alleviate the chelating effects.

\section{AKNOWLEDGEMENT}

Financial support provided by Wageningen University through the North-South Interdisciplinary Research and Education Fund (INREF) is gratefully acknowledged. The International Foundation for Science, Stockholm, Sweden is acknowledged for financial support to A. P. P. Kayodé (Grant $N^{\circ}$ IFS E/3736-1).

\section{REFERENCES}

1 Svanberg U and Lorri W, Fermentation and nutrient availability. Food Control 8:319-327 (1997).

2 Frossard E, Bucher M, Mächler F, Mozafar A and Hurrell R, Potential for increasing the content and bioavailability of $\mathrm{Fe}$, $\mathrm{Zn}$, and $\mathrm{Ca}$ in plants for human nutrition. I Sci Food Agric 80:861-879 (2000).

3 Graf E, Chemistry and application of phytic acid: An overview, in Phytic Acid: Chemistry and Application, ed. by Graf E. Pilatus Press, Minneapolis, pp. 1-21 (1986).

4 Duodu KG, Taylor JRN, Belton PS and Hamaker BR, Factors affecting sorghum protein digestibility. I Cereal $\mathrm{Sci}$ 38:117-131 (2003).

5 Hounhouigan DJ, La valorisation des céréales locales pour les marchés urbains en Afriques de l'Ouest: les atouts, contraintes et perspectives, in Food Based Approaches for
A Healthy Nutrition in West Africa; Proceedings of the 2nd international workshop, ed. by Brouwer ID, Traore AS and Treche S. University of Ouagadougou; Institute for Development Research, Montpellier; Wageningen University; Food and Agriculture Organization, Rome, Ouagadougou, pp. 359-368 (2004).

6 Kayodé APP, Adégbidi A, Linnemann AR, Nout MJR and Hounhouigan DJ, Quality of farmer's varieties of sorghum and derived foods as perceived by consumers in Benin. Ecol Food Nutrition 44:271-294 (2005).

7 Brekke OL and Kwolek WF, Corn dry-milling: cold-tempering and degermination of corn of various initial moisture content. Cereal Chem 46:545-559 (1969).

8 Reichert RD, Sorghum dry milling, in Sorghum in the Eighties, Proceedings of the International Symposium on Sorghum, 2-7 November 1981, Patancheru, AP, India (Vol. 2). ICRISAT, Patancheru, AP, India, pp. 547-564 (1982).

9 Sahay KM, Evaluation of a general purpose abrasive mill for pearling of coarse cereals and dehusking of pulses. Int $\mathcal{F}$ Food Sci Technol 25:220-225 (1990).

10 Beta T, Rooney LW, Marovatsanga L and Taylor JRN, Phenolic compounds and kernel characteristics of Zimbabwean sorghums. I Sci Food Agric 79:1003-1010 (1999).

11 Fretzdroff B and Weiper D, Phytic acid in cereals: phytase in rye and rye products. Zeitschrift fur Lebensmittel Untersuchung und - Forschung 82:287-293 (1986).

12 Wanasundera JPD and Ravindran G, Effect of cooking on the nutrient and antinutrient contents of yam tubers (Dioscorea alata and Dioscorea esculenta). Food Chem 45:247-250 (1992).

13 Mahgoub SEO and Elhag SA, Effect of milling, soaking, malting, heat-treatment and fermentation on phytate level of four Sudanese sorghum cultivars. Food Chem 61:77-80 (1998).

14 Duhan A, Khetarpaul N and Bishnoi S, Content of phytic acid and $\mathrm{HCl}$-extractability of calcium, phosphorus and iron as affected by various domestic processing and cooking methods. Food Chem 78:9-14 (2002).

15 Kiers JL, Nout MJR and Rombouts FM, In vitro digestibility of processed and fermented soya bean, cowpea and maize. $7 \mathrm{Sci}$ Food Agric 80:1325-1331 (2000).

16 Temminghof E, Soil and Plant Analysis. Part 3. Plant analysis procedures. Wageningen University Environmental Sciences, Wageningen (1997).

17 Bentsink L, Yuan K, Koornneef $M$ and Vreugdenhil D, The genetics of phytate and phosphate accumulation in seeds and leaves of Arabidopsis thaliana, using natural variation. Theoret Appl Genet 106:1234-1243 (2003).

18 Cia T, Ejeta G and Butler LG, Screening for grain polyphenol variants from high-tannin sorghum somaclones. Theoret Appl Genet 90:211-220 (1995).

19 Singleton VL and Rossi JA, Colorimetry of total phenolic compounds with phosphomolybdic phosphotungstic acid reagents. Am F Enol Viticul 16:144-158 (1965).

20 American Association of Cereal Chemists, Approved Methods of the $A A C C, 8^{\text {th }}$ edn. AACC, St Paul, Minnesota (1984).

21 Mestres C, Dorthe S, Akissoe N and Hounhouigan DJ, Prediction of sensorial properties (colour and taste) of amala, a paste from yam flour of West Africa, through flour biochemical properties. Plant Foods for Human Nutrition 59:93-99 (2004).

22 Kayode APP, Linnemann AR, Hounhouigan JD, Nout MJR and Van Boekel M, Genetic and environment impact on iron, zinc, and phytate in food sorghum grown in Benin. 7 Agric Food Chem 54:256-262 (2006).

23 Jambunathan $\mathrm{R}$, Improvement of the nutritional quality of sorghum and pearl millet. Food Nutr Bull 2:11-16 (1980).

24 Traoré $\mathrm{T}$, Mouquet $\mathrm{C}$, Icard-Vernière $\mathrm{C}$, Traoré AS and Trèche $S$, Changes in nutrient composition, phytate and cyanide contents and $\alpha$-amylase activity during cereal malting in small production units in Ouagadougou (Burkina Faso). Food Chem 88:105-114 (2005). 
25 Reddy NR, Occurrence, distribution, content, and dietary intake of phytate, in Food Phytates, ed. by Reddy NR and Sathe SK. CRC Press, Boca Raton, pp. 25-52 (2002)

26 Barroga CF, Laurena AC and Mendoza EMT, Polyphenols in mung bean (Vigna radiata (L.) Wilczek): determination and removal. f Agric Food Chem 33:1006-1009 (1985).

27 Ekpenyong TE, Effect of cooking on polyphenolics content of some Nigerian legumes and cereals. Nutrition Reports International 31:561-565 (1985).
28 Matuscheck E, Towo E and Svanberg U, Oxidation of polyphenols in phytate-reduced high-tannin cereals: Effect on different phenolic groups and on in vitro accessible iron. $\mathcal{F}$ Agric Food Chem 49:5630-5638 (2001).

29 Lestienne I, Icard-Vernière C, Mouquet C, Picq C and Trèche $\mathrm{S}$, Effect of soaking whole cereal and legume seeds on iron, zinc and phytate contents. Food Chem 89:421-425 (2005). 